\title{
BIOCHEMICAL INVESTIGATIONS OF MURINE LEPROSY BACILLI
}

\section{( I ) Collection of Murine Leprosy Bacilli from Infected Tissue}

\section{Tonetaro ITO}

Research Institute for Microbial Diseases, Osaka University

\section{Ryuzo SONODA}

Department of Dermatology, Osaka University Medical School

Various methods for collecting murine leprosy bacilli in pure form and in high concentration were tried and evaluated by comparative tests in rats. The following methods were tested ( a ) centrifugation (b)pretreatment with trypsin and then centrifugation and (c) pretreatment with trypsin followed by the Hanks concentration method. The following results were obtained.

The yield was $13 \%$ with (a), $21 \%$ with (b) and $11 \%$ with (c). In other words, the method of pretreatment with $0.1 \%$ trypsin for 1 hour at $37^{\circ} \mathrm{C}$ (b method) gave the best results. It was found that the activity of the bacilli was not affected by this treatment.

\section{鼠癩菌の生物化学的研究}

\section{第 1 報＼cjkstart感染組織よりの鼠癩菌の集菌に関する研究}

\author{
大阪大学微生物病研究所剩研究部 \\ 伊 藤 利 根 太毁 \\ 大阪大学医学部皮膚科教室（主任：藤浪得-:教授）

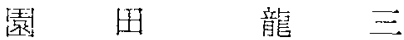

(昭和 32 年 4 月 20 日 受稿)

緒

言

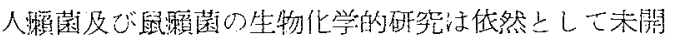

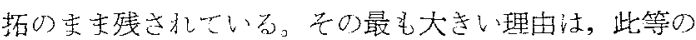

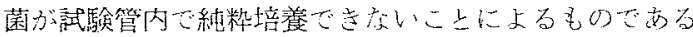

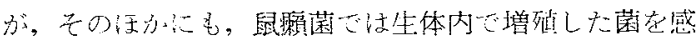

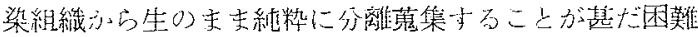
ヒ市ったこ上による。

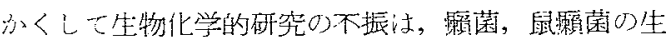
態に何等の新知見を加皇るこ上ができないで，てれ方゙

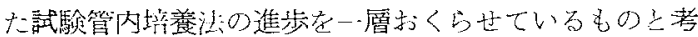
元的疓。

本題で述べようとする赫告は主として鼠瀨菌の物質代

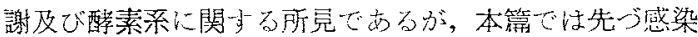

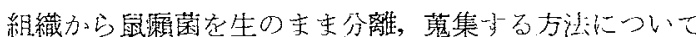
われれれの考按とその実験成績炎述心゙上うと思う。
実 験 方 法

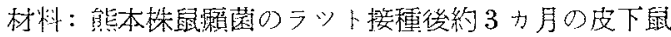

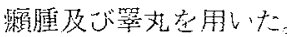

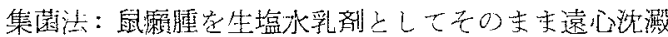

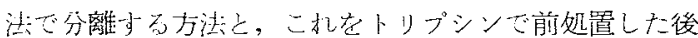
に遠心沈激法により集菌与る方法老考按し，更にHanks

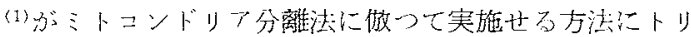
ブシンを作用せしめたい犼 Hanks 变洼（中村氏報台 による）ともいうべき方法の3つについて数次に亘つて 箺験し，最後に间一材料を以てその成績を比較した。

a) 薏门论澱集菌汒

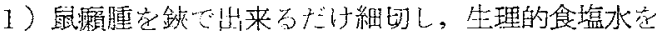
約10倍の割合に加え，ホモジナイザーにて数分間磨 碎し乳風上一字名。

2) 2500 R.P.M. 10 分閴遠心沈澱にて先づ粗大組織 


\section{空除去一产。}

3)上清芯 10,000 R.P.M. 20 分間遠心沈激。

4) 沈泾蒸溜水- 10,000 R.P.M. 20 分間遠心沈浿 法にて 3 回洗棌し，残余組織成分起除去与る。

5 ) 最終沈沿农蒸溜水て再浮游与。

b ）トリプシン前処置遠沈集菜法

1）鼠潭腫缺で出来るだけ細切し，生理的食塩水范 約10倍の割合に加点，更にホモジナイザーにて数分

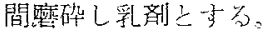

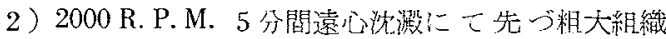
忞除去吉万

3) $0.2 \%$ トリ゙シン(バイエル】級訊菜) 溶液等 單加元て（終末濃度：0.1\%トリプシン), 粰莭器 内に $37^{\circ} \mathrm{C} 工$ 時間放置与る。

4）再び，2000 R.P.M. 5 分間遠心沈澱にて粗大組織 老除去等古。

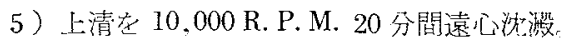

6 ）沈滥在蒸溜水で 10,000 R.P.M. 20 分閒遗心沈溉 法にて 3 回沙滌与る。

7) 最終沈渣を蒸沙水で再浮游与る。

c) Hanks 氏変江:

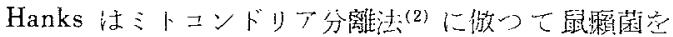

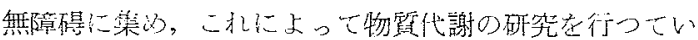

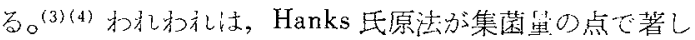

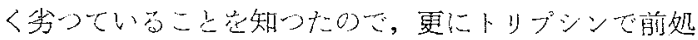
置吉光中村氏の方法在併用した。

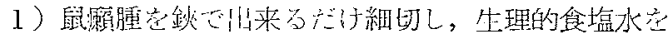
約10偣の割合に加え，ホモジナイザーにて数分間繁 确し乳都之一。。

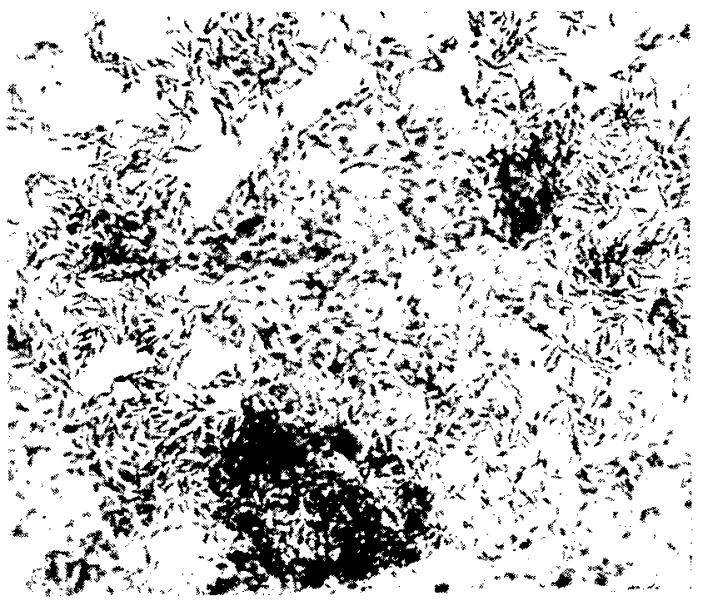

Fig. I：トリブシン前処置遠湠箱菌洼により 集的た鼠顆菌
2）2000 R.P.M. 5 分間遠心沈㳻にて粗大組織老除去 专る。

3） $0.2 \%$ トリプシン滨液等量加えて(終末濃度：0.

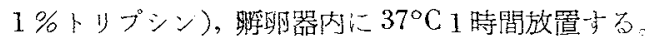

4.) $0.4 \mathrm{M}$ サッカローズ $(13.6 \%)$ を等量加关てサッ カローズの終末濃度志 $0.2 \mathrm{M}(6.8 \%)$ と卞る。

5) 之致 $4: 5$ の比で $0.3 \mathrm{M}(10.2 \%)$ サッカローズけ

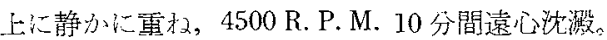

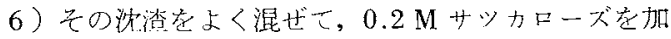
允て $12 \mathrm{cc}$ に再浮游与。寺して $1.5 \mathrm{M} \mathrm{KCl}(11 \%)$ の) $15 \mathrm{cc}$ 上に静汃に重权て 4500 R. P. M. 10 分間遠 心沈澱。

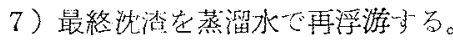

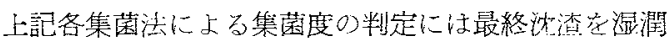

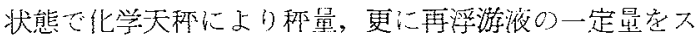
ライド梁抹 Ziehl-Neelsen 染色法を施して菌の多寞並に

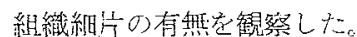

\section{実 験 成 績}

出発材料として熊本株接種 3 力月後のラット皮下鼠制

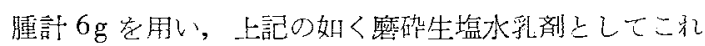

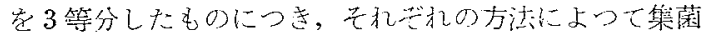

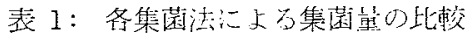

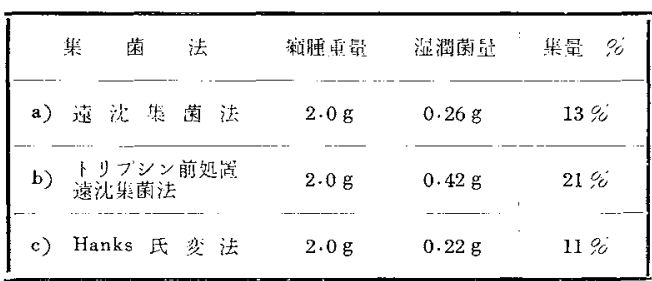

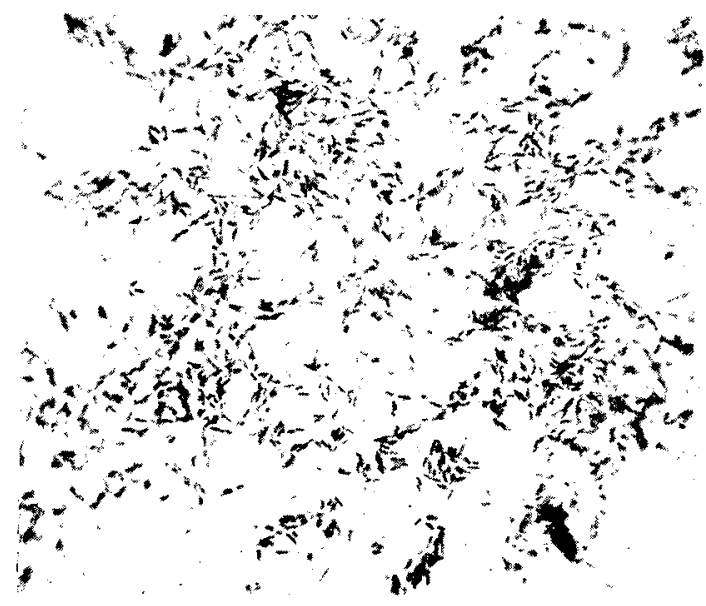

Fig. II：Hanks 氏变江汇上り集虾た鼠瀨菌 
し，化学天科て科星した。収量は表 1 の如くである。

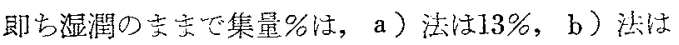
$21 \%$ で最高志し，c）法注11\%で最低であつた。

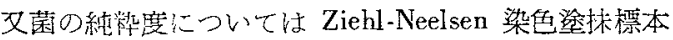

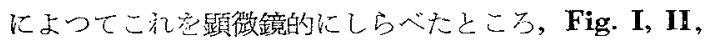

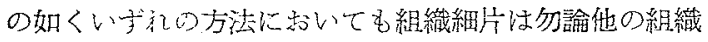

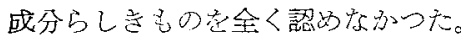

菌の活力に関しては，マウス皮下接種泛によつて䗝し

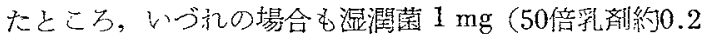
ce に相当) 接䡃で 3 力号以内に発店した。

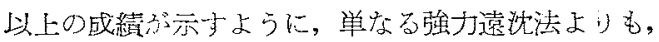
これ范 $0.1 \%$ 告トプシンで $37^{\circ} \mathrm{C} 1$ 時間処置する方法が 収量を增子上により良好であつた。そしてトリプシン融 解法在施してき Hanks 氏法の如くサツカロージーKCl

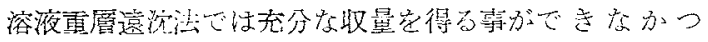
t。

\section{総括並に考按}

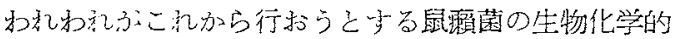

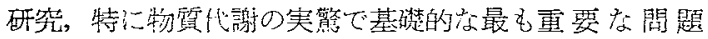

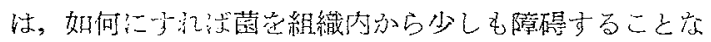

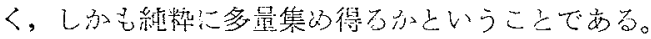

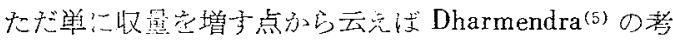

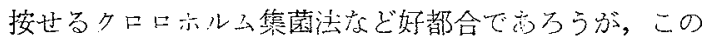

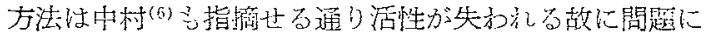

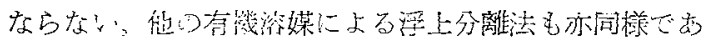
古。

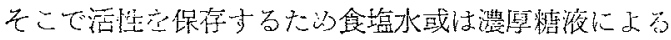

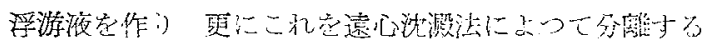

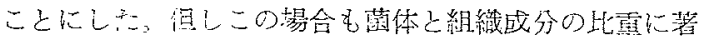

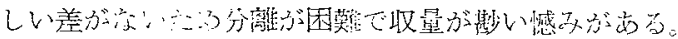

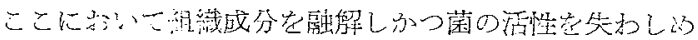

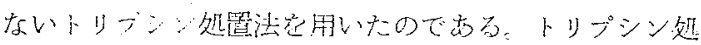

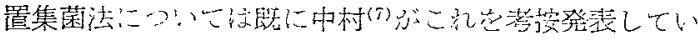

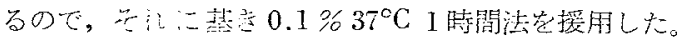

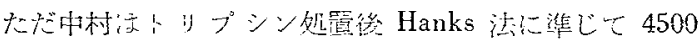

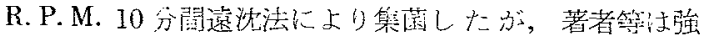

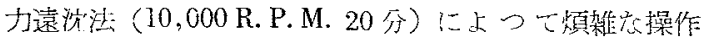

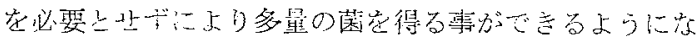
辰。

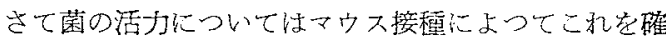

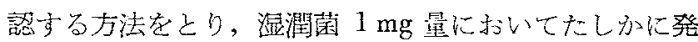
症を諗めた加，乙かしホモジナイザーによる物理的作 用，トリプシン消化による影響などが全然無視されてよ いとは常識上からも考治られないので，この点について は更に検討定加えねばならない。ただ或る程度活力定保 持している菌を比較的管学に多量蒐集できる方渠しして われわれの考按したトリプシン前処置強力遠氿集菌法が

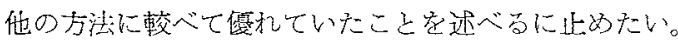

結語

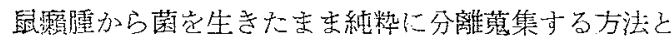

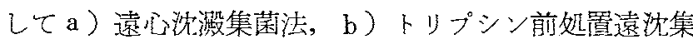
菌法，c）トリプシン前処置 Hanks 集菌法の3つ齐考

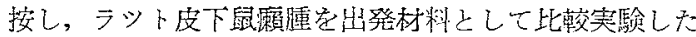
ところb）泣が最方良好な成績を示した。

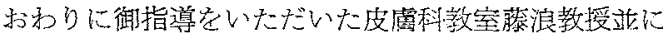

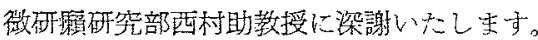

\section{文献}

1) Hanks, J. H.: Measurement of the hydrogen trans fer capacity of Mycobacteria. J. Bact., 62521 (1951)

2) Hogeboom, G. H., Schneider, W. C. and Palade,

G. E.: Cytochemical studies of mammalian tissues.

J. Biol. Chem., 172610 (1948)

3) Hanks, J. H.: The biological significance of the hydrogen transfer capacity of murine leprosy bacilli.

J. Bact., 62529 (1951)

4) Gray, C. T.: The respiratory metabolism of murine leprosy bacilli. J. Bact., 64305 (1952)

5) Dharmendra: The Lepromin Test, A Review. Leprosy Review, Vol. 18, No. 4, 92 (1947)

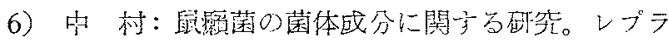
252 㝵 83 (1956)

7) Nakamura, M.: Attempts to approach to the Clarification of Chemical Composition of Mycobacterium leprae murium (III) Clemical Composition of the Bacilli separated from the Subcutaneous Tissue of Rat infected with Mycobacterium leprae murium by Pretreatment with Trypsin. Kurume, M. f. 3133 (1956) 